B. Fundamental Human Rights Principles Facing New Challenges 


\title{
How many Strikeouts are too many? The ECtHR's Evolving Approach to Repetitive Cases and the Limits of Efficiency
}

\author{
Edith Wagner
}

\section{A. The Increase in Strikeouts}

Three strikes and the batter is out is a fundamental rule of baseball. ${ }^{1}$ The ideal number of strikeouts per season, however, is a topic of endless debate. Some embrace strikeouts as a trade-off for more home runs and essential part of game management; others argue that too many strikeouts spoil the game and blame the rising strikeout rate for the declining interest in major league baseball. ${ }^{2}$ With strikeouts at an all-time high, league officials are wondering why the game is changing and what to do about it. ${ }^{3}$ But how many strikeouts are too many? And what rules, if any, could be introduced to find the sweet spot between what is entertaining and what is efficient? To learn about the latest crisis of a quintessentially American sport in a piece about a genuinely European institution like the European Court of Human Rights ('ECtHR' or 'the Court') might strike the reader as odd. And yet, the parallels between the two are striking: the quest for efficiency, rise of statistics and constant performance evaluation led to a steady increase in strikeouts. The Court's largest strikeout so far - Burmych and others $v$. Ukraine $e^{4}$ resulted in the dismissal of 12,148 applications in one judgment. ${ }^{5}$

1 Major League Baseball, Official Playing Rules Committee, Official Baseball Rules, 2018 Edition, http://mlb.mlb.com/documents/0/8/0/268272080/2018_Official_Base ball_Rules.pdf, 126.

2 Verducci, 'There Are Too Many Strikeouts in Baseball: Here's How to Fix the Problem', Sports Illustrated, 14 June 2018, https:/www.si.com/mlb/2018/06/14/stri keouts-effect-major-league-baseball.

3 Kepner, 'More Strikeouts Than Hits? Welcome to Baseball's Latest Crisis', New York Times, 16 August 2018, https://www.nytimes.com/2018/08/16/sports/baseball -mlb-strikeouts.html.

4 ECtHR, Judgment (GC), 12 October 2017, Burmych and Others $v$ Ukraine, Application Nos. 46852/13 and 4 more.

5 Ibid., para. $200 \mathrm{ff}$. and fourth operative provision. 
With the Burmych judgment, the victims of the Chernobyl disaster, who make up a fair share of the applicants, lost the legal battle over the payment of social benefits under Ukrainian law for losing their health, homes and livelihood in the nuclear accident of $1986 .{ }^{6}$ The Court did not distinguish the cases of public servants claiming outstanding salaries and other creditors seeking to collect debts from state-owned enterprises from the cases of particularly vulnerable applicants who suffer from the long-term effects of the Chernobyl disaster. Instead, the Court examined all applications through the lens of 'non-enforcement or delayed enforcement of domestic court decisions ${ }^{7}$ and opted for a one-size-fits-all strikeout by which it transferred the five applications that had been examined on the merits along with the 12,143 applications that are listed in the two appendices to the Burmych judgment to the Committee of Ministers of the Council of Europe, a body that supervises the execution of judgments at the domestic level. ${ }^{8}$ Since the early 2000s, Ukraine had been condemned repeatedly - not least by way of a pilot judgment in Ivanov $v$. Ukraine 9 - for the many flaws in the Ukrainian legal system that make it practically impossible to enforce rulings against the Ukrainian State. ${ }^{10}$ Ukraine never complied with the Court's findings and the Ivanov pilot judgment remained just as unenforced as the decisions of Ukrainian courts which, in turn, led to even more applications challenging the violation of Article 6 para. 1 European Convention on Human Rights ('ECHR' or 'the Convention') before the ECtHR.

So far, the mass strikeout in Burmych has been examined from the perspective of individual justice and the rights of the applicants, ${ }^{11}$ as well as

6 Act No. 796 of 28 February 1991 on the status and social security of citizens suffering from the consequences of the Chernobyl catastrophe, as amended by Act No. 231-V of 5 October 2006, Act No. 2321-IV of 12 January 2005, Act No. 1767-IV of 15 June 2004, Act No. 429-IV of 16 January 2003, Act No. 2638-III of 11 July 2001, Act No. 2400-III of 26 April 2001, Act No. 230 of 6 June 1996, Vidomosti Verkhovnoj Rady, No. 16, 1991, 414-439.

7 ECtHR, Judgment (GC), 12 October 2017, Burmych and Others $v$ Ukraine, Application Nos. 46852/13 and 4 more, para. 3.

8 Appendix I lists the 7,641 applications which had already been communicated to the Ukrainian Government; Appendix II the 4,502 non-communicated applications.

9 ECtHR, Judgment, 15 October 2009, Yuriy Nikolayevich Ivanov v Ukraine, Application No. 40450/04.

10 ECtHR, Judgment (GC), 12 October 2017, Burmych and Others $v$ Ukraine, Application Nos. 46852/13 and 4 more, para. 148.

11 Kindt, 'Giving up on individual justice? The effect of state non-execution of a pilot judgment on victims' (2018) 36 Netherlands Quarterly of Human Rights, 173. 
regarding its compatibility with the Convention and the implications for the relationship between the Court and the Committee of Ministers. ${ }^{12}$ What is still missing in the academic discussion is the impact of strikeouts on the Court, in particular its legitimacy and perceived fairness, along with a critical appraisal of the Court's quest to deal more efficiently with repetitive cases through procedures like the strikeout of applications under Article 37 para. 1 lit. c ECHR. Just like in baseball, the opinion on strikeouts is divided: the majority of the Grand Chamber saw the discontinuation of the proceedings as a worthy trade-off to adjudicate more non-repetitive cases and praised it as efficient case management, ${ }^{13}$ while the dissenting judges argued that the Court was 'shooting itself in the foot' by boosting the Court's statistical record without insisting on compliance with the existing obligations of Ukraine under the Convention. ${ }^{14}$ But even if we accept the use of strikeouts to deal more efficiently with repetitive cases, how many strikeouts are too many? And can the Court find the sweet spot between what is efficient and what is legitimate when striking down cases in bulk?

To address these questions, the article is divided into four parts. After an overview of the challenges entailed by repetitive cases, the increase in strikeouts at the Court and the evolving procedural approach to the Ukrainian 'non-enforcement' cases, the article embarks on a critical appraisal of the Court's reasoning in the Burmych judgment. This is followed by a general inquiry into some of the broader questions that arise under the Burmych judgment: the absolute prioritization of non-repetitive over repetitive cases that are essentially a symptom of long-term non-compliance and the sociological legitimacy of the ECtHR. The further development of the Convention, so the conclusion, is just as important to keep the Convention 'alive' as holding the member states accountable for failing to comply with their existing obligations under the Convention.

12 Ulfstein and Zimmermann, 'Certiorari through the Back Door? The Judgment by the European Court of Human Rights in Burmych and Others v. Ukraine in Perspective' (2018) 17 The Law and Practice of International Courts and Tribunals, 289.

13 ECtHR, Judgment (GC), 12 October 2017, Burmych and Others $v$ Ukraine, Application Nos. $46852 / 13$ and 4 more, para. $174 \mathrm{f}$.

$14 I d$., Joint Dissenting Opinion of Judges Yudkivska, Sajó, Bianku, Karakaş, De Gaetano, Laffranque and Motoc, para. 202. 


\section{B. Strikeouts and Repetitive Cases}

In order to gain a better understanding of the Court's ruling in Burmych, it is necessary to take a moment to reflect on repetitive cases and the increase in strikeouts at the Court. The strikeout of applications is regulated by Article 37 para. 1 ECHR:

The Court may at any stage of the proceedings decide to strike an application out of its list of cases where the circumstances lead to the conclusion that: (a) the applicant does not intend to pursue his application; or (b) the matter has been resolved; or (c) for any other reason established by the Court, it is no longer justified to continue the examination of the application. However, the Court shall continue the examination of the application if respect for human rights as defined in the Convention and the protocols thereto so requires.

A strikeout is relatively unproblematic if the applicant decides on her own motion not to continue the case or if the legal issues that had given rise to the application have been resolved. When ruling on the discontinuation of the proceedings under Article 37 para. 1 lit. c ECHR, the Court has considerable discretion which raises difficult questions as to when it is indeed justified to dismiss an application that is well-founded, let alone an entire group of more than 10,000 cases.

Unlike in baseball, the Court does not keep a public strikeout record. However, it is possible to come to an estimate of how many applications are struck down by the Court each year. A strikeout under Article 37 para. 1 ECHR is normally performed by decision unless the Grand Chamber, which must hand down judgments under Article 43 para. 3 ECHR, is ruling on the matter. ${ }^{15}$ That means the approximate number of applications that were subject to a strikeout under Article 37 para. 1 ECHR can be obtained by subtracting the number of inadmissibility decisions from the total number of applications in which a decision was rendered - a number that is reported in the Court's annual reports. ${ }^{16}$ As the table below shows,

15 Separate decisions on admissibility have been rendered in, e.g., ECtHR, Decision, 15 June 2017, Harkins $v$ the United Kingdom, Application Nos. 71537/14; ECtHR, Decision, 1 March 2010, Demopoulos and Others $v$ Turkey, Application Nos.46113/99 and 7 more; ECtHR, Decision, 2 May 2007, Behrami and Behrami $v$ France and Saramati $v$ France, Germany and Norway, Application Nos. 71412/01 and $78166 / 01$.

16 Around $90 \%$ of all applications that are received by the Court are dismissed as inadmissible for not complying with the substantive requirements of Article 35 
the number of applications in which a strikeout decision was rendered oscillates between 3,016 and 8,974 - a mean of 5,474 applications - per year and has increased significantly from 2011 onwards. ${ }^{17}$ The increase in strikeouts must be seen in light of the reduction of the number of pending applications before the ECTHR since 2011. After reaching an all-time high of 151,600 in 2011 , the number of pending cases has steadily declined since then: to 99,900 applications in $2013 ; 64,850$ in 2015 , and 56,350 in 2018. ${ }^{18}$

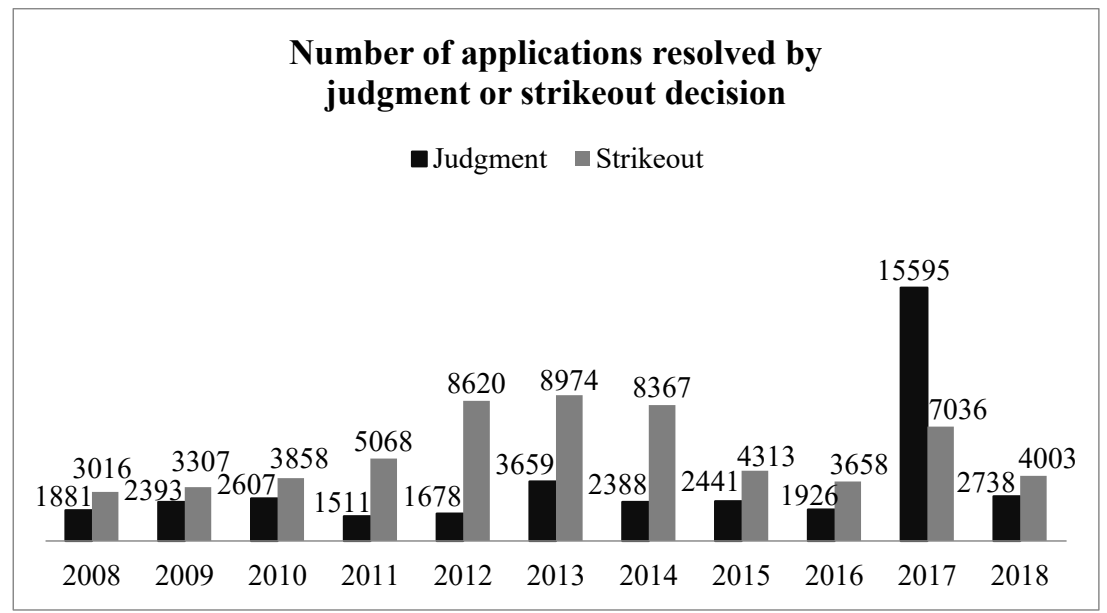

Nearly $50 \%$ of the pending cases are so-called repetitive cases. In other words, every second case that is decided by the Court is repetitive. Just to give an example, in 2015 alone, the Court adjudicated some 30,500 repetitive cases. ${ }^{19}$ As the name indicates, a repetitive case is a type of case that requires the Court to repeat the same findings, often many hundreds of times. Repetitive cases are a symptom of persistent systemic issues at the

ECHR, notably the six-month time limit and the exhaustion of all domestic remedies, or the formal requirements of Rule 47 of the Rules of Court.

17 Table made by the author. For data, see Annex.

18 ECtHR, Annual Report 2018, https://www.echr.coe.int/Documents/Annual_repo rt_2018_ENG.pdf, 167; Annual Report 2015, https://www.echr.coe.int/Document s/Ānnual_report_2015_ENG.pdf, 187; Annual Report 2013, https://www.echr.coe .int/Documents/Ānnual_report_2013_ENG.pdf, 191.

19 ECtHR, Annual Report 2015, https://www.echr.coe.int/Documents/Annual_Repo rt_2015_ENG.pdf, 5. 
domestic level that affect entire groups of individuals. More often than not, the Court's case law on the underlying legal issue is well-established. Still, the Court needs to re-examine the merits given that each case is wellfounded and filed by a different applicant. To adjudicate repetitive cases more efficiently, the Court's procedural toolbox has been enlarged considerably. While rulings in well-founded applications could only be handed down by a seven-judge Chamber in the past, the Court can choose between various procedures for repetitive cases: the pilot judgment procedure under Rule 61 of the Rules of Court ${ }^{20}$, the procedure for well-established case law under Article 28 ECHR, friendly settlements under Article 39 ECHR, unilateral declarations under Rule 62a of the Rules of Court and strikeouts under Article 37 para. 1 ECHR.

\section{The Widespread Disregard for the Obligations under the Convention}

More often than not, repetitive cases are portrayed as a burden ${ }^{21}$, an existential threat that diverts the Court from allegedly more meritorious non-repetitive cases that contribute to the substantive development of the Convention. ${ }^{22}$ As convincing as this may sound at first, it is oversimplifying a highly complex reality and misses one crucial point: repetitive cases as such do not put the Court to the test. Had the Court the budget and staff it actually needed, ${ }^{23}$ it could adjudicate both repetitive and non-repetitive cases without having to choose between a rock and a hard place: a backlog of repetitive cases or less substantive development of the Convention. What really threatens the Strasbourg system is the fact that many countries ignore their most pressing problems - be it for practical, financial or political reasons - and disregard their existing obligations under the Convention. Long-term non-compliance paired with the lack of effective local remedies lead to countless repetitive cases each year.

20 ECtHR, Rules of Court, 2020 https://www.echr.coe.int/Documents/Rules_Court_ ENG.pdf.

21 The Court word burden is used several times across the judgment when discussing the challenges entailed by repetitive cases, see ECtHR, Judgment (GC), Burmych and Others $v$ Ukraine, Application Nos. 46852/13 and 4 more, paras. 8, 134, 174, 201.

22 Sainati, 'Human Rights Class Actions: Rethinking the Pilot-Judgment Procedure at the European Court of Human Rights' (2015) 56 Harvard International Law Journal, 147.

23 The Court does not have its own budget. Its expenditures are borne by the Council of Europe under Article 50 ECHR. 
An application with the ECtHR is often the only way to address the ailments of many European countries:

- Inadequate conditions of detention like lack of space, hygiene, or food, or ill-treatment by prison guards amounting to inhuman or degrading treatment under Art 3 ECHR. 24

- The disenfranchisement of convicted felons violating the right to free elections under Art 3 of Protocol No. 1 to the Convention. ${ }^{25}$

- Various issues violating ownership rights under Art 1 of Protocol No. 1 to the Convention. ${ }^{26}$

- Delayed justice in civil, administrative, and criminal proceedings that violate the reasonable time requirement of the right to a fair trial under Article 6 ECHR. ${ }^{27}$

24 ECtHR, Judgment, 10 January 2012, Ananyev and Others $v$ Russia, Application Nos. 42525/07 and 60800/08; ECtHR, Judgment, 8 January 2013, Torreggiani and Others $v$ Italy, Applications Nos. 43517/09 and 6 more; ECtHR, Judgment, January 2015, Neshkov and Others v Bulgaria; Application Nos. 36925/10 and 5 more; ECtHR, Judgment, 10 March 2015, Varga and Others $v$ Hungary, Application Nos. 14097/12 and 5 more; ECtHR, Judgment, 6 September 2016, W. D. v Belgium, Application No. 73548/13.

25 ECtHR, Judgment, 23 November 2010, Greens and M. T. $v$ the United Kingdom, Application Nos. 60041/08 and 60054/08.

26 ECtHR, Judgment (GC), 22 June 2004, Broniowski v Poland, Application No. 31443/96; ECtHR, Judgment (GC), 19 June 2006, Hutten-Czapska v Poland, Application No. 35014/97; ECtHR, Judgment, 3 November 2009, Suljagić v Bosnia and Herzegovina; Application No. 27912/02; ECtHR, Judgment, 12 October 2010, Maria Atanasiu and Others v Romania, Application Nos. 30767/05 and 33800/06; ECtHR, Judgment, 31 July 2012, Manushaqe Puto and Others $v$ Albania, Application Nos. 604/07 and 3 more; ECtHR, Judgment, 3 September 2013, M. C. and Others $v$ Italy, Application No. 5376/11; ECtHR, Judgment (GC), 16 July 2014, Alisic and Others $v$ Bosnia and Herzegovina, Croatia, Serbia, Slovenia and The former Yugoslav Republic of Macedonia, Application No. 60642/08.

27 ECtHR, Judgment, 2 September 2010, Rumpf $v$ Germany, Application No. 46344/06; ECtHR, Judgment, 21 December 2010, Vassilios Athanasiou and Others $v$ Greece, Application No. 50973/08; ECtHR, Judgment, 10 May 201, Dimitrov and Hamanov v Bulgaria, Application. Nos. 48059/06 and 2708/09; ECtHR, Judgment, 10 May 2011, Finger v Bulgaria, Application No. 37346/05; ECtHR, Judgment, 20 March 2012, Ümmühan Kaplan v. Turkey, Application. no. 24240/07; ECtHR, Judgment, 3 April 2012, Michelioudakis v Greece, Application No. 54447/10; ECtHR, Judgment, 30 October 2012, Glykantzi v Greece, Application No. 40150/09; ECtHR, Judgment, 7 July 2015, Rutkowski and Others $v$ Poland, Application Nos. 72287/10, 13927/11, 46187/11; ECtHR, Judgment, 16 July 2015, Gazsó v Hungary, Application No. 48322/12. 
- And, last but not least, the issue that lies at the heart of the Burmych judgment: a violation of the right to enforcement within reasonable time along with an effective domestic remedy that speeds up the enforcement and grants compensation for undue delays under Article 6 para. 1 and Article 13 ECHR. ${ }^{28}$

\section{Ukraine and the Chernobyl Victims}

The reason why the rulings remain unenforced in Ukraine is straightforward: the Ukrainian State owes the money and the treasury is empty. The creditors are Chernobyl victims like Lidiya Burmych that are entitled to various social payments, military servicemen and public servants that are claiming their outstanding salaries and allowances, and other creditors seeking enforcement of money judgments against enterprises that are owned by the Ukrainian State. All in all, the Court has received over 29,000 repetitive cases from applicants that had been unable to enforce the respective domestic court decision against the Ukrainian State. Since 2016, around 200 new applications were filed per month. Judgments on the merits were adopted in 3,491 cases, friendly settlements in 1,103 cases, unilateral declarations in 1,233 cases, and single judge decisions in 8,274 cases.

\section{The Court's Evolving Procedural Approach}

In order to understand the strikeout in Burmych, it is important to consider how the Court's procedural approach to Ukrainian non-enforcement cases evolved over time.

28 ECtHR, Judgment, 15 October 2009, Yuriy Nikolayevich Ivanov v Ukraine, Application No. 40450/04; ECtHR, Judgment (GC), 12 October 2017, Burmych and Others $v$ Ukraine, Application Nos. 46852/13 and 4 more; ECtHR, Judgment, 15 January 2009, Burdov v Russia (No. 2), Application No. 33509/04; ECtHR, Judgment, 28 July 2009, Olaru and Others $v$ Moldova, Application Nos. 476/07, 22539/05, 17911/08, 13136/07. 


\section{2001 to 2009: The First Friendly Settlement and Case-by-Case Adjudication}

In 2001, in the first case addressing the non-enforcement of judgments in Ukraine - Kaysin and Others v. Ukraine ${ }^{29}$ - a friendly settlement was reached and the monetary compensation paid by Ukraine. Yet, the general issue of non-enforcement remained unresolved. Between 2001 and 2004, more repetitive cases were received, and judgments were adopted on a case-by-case basis. ${ }^{30}$

\section{2009: The Pilot Judgment Procedure}

In 2009, the Court decided to apply the pilot judgment procedure in the case Ivanov $v$. Ukraine. ${ }^{31}$ The pilot judgment obliged Ukraine to address the structural problem - the lack of funds, the passiveness of the bailiffs, and the shortcomings in the national legislation - which made it impossible for Mr. Ivanov and 1,400 other applicants to enforce their judgments. In the aftermath of the pilot judgment, the Ukrainian Government requested two extensions of the deadline set by the Court to introduce a new local remedy. One extension was granted, the second declined, ${ }^{32}$ and the Court agreed to adjourn the examination of the pending cases until July 15th, 2011. In June 2012, a domestic remedy was finally introduced, but turned out to be ineffective. ${ }^{33}$

29 ECtHR, Judgment, 3 May 2001, Kaysin and Others $v$ Ukraine, Application No. 46144/99.

30 See, inter alia, ECtHR, Judgment, 29 June 2004, Voytenko v Ukraine, Application No. 18966/02; ECtHR, Judgment, 27 July 2004, Romashov v Ukraine, Application No. 67534/01; ECtHR, Judgment, 26 April 2006, Zubko and Others $v$ Ukraine, Application No. 3955/04; ECtHR, Judgment, 29 November 2005, Belanova v Ukraine, Application No. 1093/02; ECtHR, Judgment, 15 December 2005, Kucherenko v Ukraine, Application No. 27347/02; ECtHR, Judgment, 20 July 2004, Shmalko v Ukraine, Application No. 60750/00; ECtHR, Judgment, 18 January 2005, Poltorachenko $v$ Ukraine, Application No. 77317/01.

31 ECtHR, Judgment, 15 October 2009, Yuriy Nikolayevich Ivanov v Ukraine, Application No. 40450/04.

32 ECtHR, Judgment (GC), 12 October 2017, Burmych and Others $v$ Ukraine, Application Nos. $46852 / 13$ and 4 more, para. $16 \mathrm{ff}$.

$33 I d$., para 27. 


\section{From 2012 to 2015: The Fast-Track Procedure}

In July 2012, the Court resumed the examination of all adjourned non-enforcement cases, and introduced a new fast-track procedure in Kharuk and Others v. Ukraine ${ }^{34}$ : the procedure for cases that concern the Court's wellestablished case law, commonly referred to as the WECL procedure, Article 28 para. 1 lit. $\mathrm{b}$ of the Convention. Under this procedure, a Committee of three judges can declare applications admissible, render judgments on the merits, and rule on just satisfaction provided that the grounds for finding a violation of the Convention are well-established in the Court's case law.

\section{The Procedure for Well-Established Case Law}

In the Ukrainian non-enforcement cases, the WECL procedure simplified and accelerated also the communication stage of the proceedings. The Court did not request any information on the admissibility and merits of the case from the Ukrainian Government; only factual observations were exchanged. In addition, the Court communicated the cases in groups, often several hundred cases per month, and the Registry prepared friendly settlement proposals for the entire group of cases. If the applicants agreed to settle the case, a voluntary payment was made by Ukraine, and the entire group of cases struck out. If no friendly settlement was reached, Ukraine could file a request to strike out the repetitive cases on the basis of a so-called unilateral declaration.

\section{Unilateral Declarations}

The Court introduced unilateral declarations in well-founded cases in Tabsin Acar v. Turkey. ${ }^{35}$ The approach is now governed by Rule 62a Rules of Court. ${ }^{36}$ In the unilateral declaration, the violation of the Convention is acknowledged and adequate redress offered. Even if the applicants want

34 ECtHR, Judgment, 26 July 2012, Kharuk and others $v$ Ukraine, Application No. 703/05 and 115 more.

35 ECtHR, Judgment (GC), 6 May 2003, Tahsin Acar v Turkey, Application No. $26307 / 95$.

36 See also ECtHR: Unilateral declarations: policy and practice, September 2012, https://www.echr.coe.int/Documents/Unilateral_declarations_ENG.pdf. 
their cases to continue, the Court can strike them out so long as the continued examination is no longer justified. Aside from the missing consent on the part of the applicant, the main difference between friendly settlements and unilateral declarations is the lack of supervision during the execution stage, a lacuna in the Convention. Only the execution of friendly settlements is subject to supervision by the Committee of Ministers under Article 39 para. 4 ECHR.

In terms of efficiency, unilateral declarations are superior to judgments. They generate less work for the Court and the procedure can easily be standardised. The member states, too, are unlikely to complain when the Court allows them to file a request for a unilateral declaration. Unilateral declarations are cheaper than friendly settlements because the awards offered are usually lower than the ones calculated by the Registry in friendly settlement agreement ${ }^{37}$ and they come with the bonus of no supervision at the execution stage. Under the current system of unilateral declarations without supervision at the execution stage, Ukraine was able to get away with long-term non-compliance. 2,234 cases had been settled through unilateral declarations between May 2015 and February 2016, but Ukraine did not always pay the sums offered under the terms of the unilateral declarations as letters by the applicants have revealed. ${ }^{38}$

\section{2017: The Mass Strikeout in Burmych}

In December 2015, a Chamber of the fifth section decided to relinquish jurisdiction in favour of the Grand Chamber to reconsider the Court's approach to non-enforcement cases filed against Ukraine. In a ten to seven majority decision, the Grand Chamber decided to discontinue the fasttrack procedure for well-established case law in Ukrainian non-enforcement cases and ruled on the strikeout of 12,148 cases that were transferred to the execution department of the Committee of Ministers of the Council of Europe. ${ }^{39}$ The list of reasons the Grand Chamber offered for this radical change of course was long. At the outset, the Court reiterated its findings in the Ivanov pilot judgment - that the structural problem was complex and required the implementation of comprehensive legislative and admin-

37 On the calculation of the awards by the Registry, see Keller et al., Friendly Settlements before the European Court of Human Rights (2010), 78.

38 ECtHR, Judgment (GC), 12 October 2017, Burmych and Others $v$ Ukraine, Application Nos. 46852/13 and 4 more, para. 40.

$39 I d$., operative provisions. 
istrative measures involving various domestic authorities 40 - and that Ukraine had failed to implement general measures addressing the root cause. In other words, the pilot judgment in Ivanov had been a failure. The Court noted also that some 120,000 people were affected by unenforced judicial decisions in Ukraine - all of whom could theoretically file an application with the Court - and that such a massive influx of applications would affect the Court's ability to fulfil its mission under Article 19 in relation to other meritorious applications warranting examination. ${ }^{41}$ Furthermore, the Court held that its judicial policy of "wholesale delivery of rulings $^{\prime 42}$ has neither had any meaningful impact on the overall systemic problem, nor led to any apparent progress in the execution process. The continued examination of the cases would, so the Court argued, result in more applicants turning to the Court for redress. This would transform the Court into a compensation commission for Ukrainian non-enforcement cases. ${ }^{43}$ Finally, the Court came to the conclusion

that nothing is to be gained, nor will justice be best served, by the repetition of its findings in a lengthy series of comparable cases, which would place a significant burden on its own resources, with a consequent impact on its considerable caseload. ${ }^{44}$

The majority considered the strikeout to be a win-win situation, where the applicants are 'more appropriately protected in the execution process', ${ }^{45}$ while the Court gets to 'focus on cases raising new and serious issues of Convention compliance'. ${ }^{46}$ This begs of course the question what is considered to be a serious issue of (non-)compliance if not the Ukrainian non-enforcement cases?

40 Id., para. 144.

41 Id., para. $149 \mathrm{f}$.

42 Id., para. 152.

43 Id., para. 155.

$44 I d$., para. 174.

45 Id. para. 202.

46 Id., para. 210. 


\section{Appraising the Judgment in Burmych}

\section{The Flawed Prioritisation of Non-repetitive over Repetitive Cases}

The decision of the Grand Chamber in Burmych illustrates that the Court's long-standing practice of prioritising new issues over repetitive issues is flawed. How can repetitive cases be considered less important than nonrepetitive cases when judgments granting social benefits that secure the survival of entire families remain unenforced? In fact, the dissenting judges

cannot agree that the present applications and the underlying miseries are less meritorious than other cases. Who could explain to incapacitated Chernobyl victims that their decades' long misery is less meritorious than the legal qualification of a single slap on the face of a young provocateur? ${ }^{47}$

The clear prioritisation of non-repetitive cases stems from the Court's mission to maintain the Convention as the often-cited 'living instrument'. ${ }^{48}$ One way, the traditional way of keeping the Convention 'alive' has been through progressive interpretive evolution. And in order to further develop the Convention, the Court needs cases that raise new legal questions. However, the Convention remains just as practically relevant when the Court reminds the member states ever so often about the problems they ignore and their duty to safeguard all the rights under the Convention within their jurisdiction, and not just the ones they agree with.

\section{The Lack of Weighing and Balancing}

It is a good question why the Court did not weigh and balance its institutional integrity and the efficient administration of justice under Article 19 ECHR with the right of the applicants to obtain a decision under Art 34 ECHR. While the Court goes through a long list of reasons to justify the strike out, it nowhere addresses the right of the 7,641 applicants whose cases had already been communicated to obtain a decision from the Court. Even if the Court had come to the same conclusion - that its procedural

47 Id., Joint Dissenting Opinion of Judges Yudkivska, Sajó, Bianku, Karakaş, De Gaetano, Laffranque and Motoc, para. 9.

48 ECtHR, Judgment, 25 April 1978, Tyrer $v$ the United Kingdom, Application No. $5856 / 72$. 
and institutional integrity prevails over the right of the individuals to assert their rights under the Convention - the decision would stand on a more solid legal ground and lose its defensive tone and language. The dissenting judges did not embark on a balancing test either, but found

it particularly troubling that such a denial of the right to an individual application $[\ldots]$ was motivated by the bureaucratic reasons of easing the burden on the Court. [...] [L]owering the number of cases pending before the Court might make the administrative situation of the institution look brighter, this does not mean that the human rights situation in Europe is any better. ${ }^{49}$

\section{The Substantive Evolution of the Convention}

It is striking that nowhere did the Court acknowledge the fact that individual justice had been delivered in more than 14,000 cases, be it through judgments on the merits, friendly settlements, or unilateral declarations. That suggests that the Court cares about individual justice only so long as it goes hand in hand with the interpretive evolution of the Convention. Only in non-repetitive cases is it possible to interpret the Convention while delivering individual justice. But what is the point of further development if many member states find themselves unable to comply with the Convention as it stands now? If we look at Article 19 ECHR, the Court was put in place 'to ensure the observance of the engagements undertaken by the High Contracting Parties in the Convention and the Protocols thereto'. And isn't the Court doing exactly that - ensuring that Ukraine observes its engagements under the Convention - when adjudicating non-enforcement cases? So, if 'the Court's role under Article 19 cannot be converted into providing individualised financial relief, ${ }^{50}$ why did the Court not discuss whether it should stop awarding just satisfaction under Article 41 ECHR?

49 ECtHR, Judgment (GC), 12 October 2017, Burmych and Others $v$ Ukraine, Application Nos. 46852/13 and 4 more, Joint Dissenting Opinion of Judges Yudkivska, Sajó, Bianku, Karakas, De Gaetano, Laffranque and Motoc, para. 39.

50 Id., para. 181. 


\section{The Lack of a Public Hearing: Perceived Procedural Fairness and Legitimacy}

Socio-legal research has shown that individuals are able to accept unfavourable outcomes without putting the legitimacy of the institution that has rendered the decision into question if the decision-making is perceived to be fair. ${ }^{51}$ Broadly speaking, there are two competing concepts of legitimacy discussed in the literature: sociological legitimacy, on the one hand, which measures legitimacy subjectively and looks at the attitudes of the applicants and other key audiences towards the ECtHR; ${ }^{52}$ normative legitimacy, on the other hand, which measures legitimacy in terms of whether certain standards are being met and considers the ECtHR's institutional transparency and procedural design, ${ }^{53}$ the quality of its jurisprudence, ${ }^{54}$ judicial independence ${ }^{55}$ and impartiality, ${ }^{56}$ the deliberation style, ${ }^{57}$ overall performance and efficiency. ${ }^{58}$ Against that backdrop, strikeouts have a disparate impact on the ECtHR's legitimacy, in theory at least. They help maximizing the Court's efficiency and thus enhance its normative legitimacy, while entailing the risk of damaging the ECtHR's sociological legitimacy if applicants that have been struck out feel treated unfairly. Put differently, strikeouts are likely to do more harm than good in the long run unless the applicants accept that they did not get the same procedural treatment as applicants in non-repetitive cases.

One way to safeguard the perceived fairness of strikeouts and mitigate the risk of damaging the Court's sociological legitimacy is to hold a public hearing. Why the judges decided to forego a public hearing, which is normally held in proceedings before the Grand Chamber, ${ }^{59}$ is unclear.

51 Tyler, Why People Obey the Law (2006).

52 See, inter alia, Cohen et al., 'Legitimacy and International Courts - A Framework', in Grossman et al. (eds), Legitimacy and International Courts (2018), 4.

53 Berkhuysen and Van Emmerik, 'Legitimacy of European Court of Human Rights Judgments: Procedural Aspects', in Huls et al. (eds), The Legitimacy of Highest Courts' Rulings (2009), 435; Lasser, Judicial Deliberations, A Comparative Analysis of Judicial Transparency and Legitimacy (2004).

54 Sellers (ed), Law, Reason, and Emotion (2017).

55 Ulfstein, 'The Human Rights Treaty Bodies and Legitimacy Challenges', in Nienke Grossman et al. (eds), Legitimacy and International Courts (2018), 284.

56 Voeten, 'The Impartiality of International Judges: Evidence from the European Court of Human Rights' (2008) 102 The American Political Science Review, 417.

57 Garlicki, 'Judicial Deliberations: The Strasbourg Perspective', in Huls et al. (eds), The Legitimacy of Highest Courts' Rulings (2009), 389.

58 Often described as output legitimacy, Scharpf, 'Legitimacy in the multilevel European polity' (2009) 1 European Political Science Review, 173.

59 Nußberger, The European Court of Human Rights (2020), 65. 
The Burmych judgment is silent on whether the applicants had expected a public hearing and which reasons had been considered by the judges when requesting written observations instead. ${ }^{60} \mathrm{~A}$ public hearing would have given the applicants the chance to confront the Ukrainian Government directly and in open court, and the other victims, who appear in the two Appendices to the Burmych judgment and thus were not directly involved in the proceedings, the opportunity to bear witness to the pleadings by the parties. Given that all public hearings are filmed and can be viewed online on the Court's website, ${ }^{61}$ all victims regardless of whether they had filed an application could have seen that the ECtHR had carefully considered the various arguments before closing the door to the victims of the Chernobyl disaster.

As a general rule, the Court has full discretion over whether or not to hold a hearing under Rule 59 para 5 of the Rules of Court the Court:

Before taking a decision on admissibility, the Chamber may decide, either at the request of a party or of its own motion, to hold a hearing if it considers that the discharge of its functions under the Convention so requires. In that event, unless the Chamber shall exceptionally decide otherwise, the parties shall also be invited to address the issues arising in relation to the merits of the application.

Hearings are generally public under Article 40 ECHR, but in exceptional cases, notably when national security interests are at stake, an additional in camera hearing can be held to discuss confidential, secret or otherwise sensitive information. ${ }^{62}$ The Court's public hearings tend to be rather structured and leave little room for courtroom dramatics. Rather than a trial-like confrontation between the parties, the purpose of holding a public hearing is to open the Court to the general public and allow outsiders to see the judges in action. ${ }^{63}$

60 ECtHR, Judgment (GC), 12 October 2017, Burmych and Others $v$ Ukraine, Application Nos. 46852/13 and 4 more, para. 7 ("Following the Grand Chamber's decision of 16 March 2016 not to hold a hearing, the applicants and the Government each filed written observations on the admissibility and merits of the applications referred to in paragraph 1 above.”).

61 Hearings held in the morning are usually available in the afternoon; hearings held in the afternoon are usually available in the evening on the Court's website (https://www.echr.coe.int) which contains a dedicated section for "Hearings" that hosts all webcasts.

62 See, inter alia, ECtHR, Judgment, 24 July 2014, Al Nashiri v Poland, Application No. 28761/11.

63 Nußberger, The European Court of Human Rights (2020), 65. 
When it comes to strikeouts, there have been instances where the Court proceeded without a public hearing based on 'the parties' implicit undertaking not to request a rehearing of the case before the Grand Chamber' ${ }^{\prime} 4$. Given that the Burmych judgment does not address the reasons that led to the lack of a public hearing, it is impossible to tell if the judges assumed that all five applicants agreed on proceeding in writing. Public hearings are unlikely leading to additional insights in repetitive cases. However, if we accept the argument that Ukraine has the willingness but not the money to compensate all applicants, an apology from the Government during the oral hearing might have served more justice than hundreds of pages of written observations prepared by legal counsel. Depending on how oral hearings are being conducted, the Court might be able to deliver justice in repetitive cases even when striking out well-founded cases. It would be interesting to test this hypothesis and ask the applicants in the Burmych case including the ones listed in the two Appendices to the Burmych judgment if they would feel any different about the Court had they been granted an oral hearing. Should the question be answered in the affirmative, the Court could consider holding more oral hearings rather than mass producing essentially identical judgments.

\section{E. Conclusion}

\section{A Call for more Realism}

Through the eyes of others, the ECtHR is often viewed as 'a beacon of hope for those who feel that justice has been denied at national level' ${ }^{65}$ Statements like this one reveal how unrealistic our expectations about the Court often are. Even if taken to extremes, the quest for efficiency and effectiveness will not enable the Court to right all the wrongs and give the victims that are being affected by repetitive issues what they deserve: justice. Still, there is this longing for an institution that validates the

64 ECtHR, Judgment, 1 October 2002, Kosa v Hungary, Application No. 43352/98, operative part.

65 ECtHR, Annual Report 2018, Speech by Koen Lenaerts, President of the Court of Justice of the European Union, given at the opening of the judicial year, 26 January 2018, 2019, https://www.echr.coe.int/Documents/Annual_report_20 18_ENG.pdf, 23 (23); Sainati, 'Human Rights Class Actions: Rethinking the Pilot-Judgment Procedure at the European Court of Human Rights' (2015) 56 Harvard International Law Journal, 147. 
sense of injustice that is felt in many parts of Europe. The ECtHR is an unlikely candidate to assume the role of 'the conscience of Europe' 66 and fill the void that dysfunctional domestic institutions have left behind. If we look at the figures ${ }^{67}$ the vast majority of applicants will not get clarity, compensation or closure, but a strikeout or inadmissibility decision along with the truth that their efforts were in vain.

At the same time, scholars should not draw overly general conclusions from Burmych even though the judgment was handed down by the Grand Chamber. While some commentators interpret Burmych as denial of certiorari - albeit through the 'backdoor'68 - it is unlikely that there will be more collective strikeouts without a compelling reason for doing so. After all, the Burmych strikeout stands at the end of a long chain of failed attempts to oblige Ukraine to safeguard the enforcement of the court decisions of the Chernobyl victims and other applicants seeking payment from the Ukrainian State. Yet one cannot help but get the impression that the Court wanted to send a message with the Burmych judgment: applicants should manage their expectations and be more realistic about what the Court can deliver when countries fail to solve their most pressing issues. In fact, the dissenting judges wonder why applicants suffering from the human rights violations that typically give rise to repetitive cases should bother filing an application with the Court. ${ }^{69}$

\section{The further Development of the Convention and Compliance with Existing Obligations}

The Court should reconsider the absolute prioritisation of non-repetitive over repetitive cases. One way - the traditional way - of preserving the Convention as the often-cited 'living instrument'70 has been through

66 Myjer et al. (eds), The Conscience of Europe, 50 Years of the European Court of Human Rights (2010).

67 See supra, 3.

68 Ulfstein and Zimmermann, 'Certiorari through the Back Door? The Judgment by the European Court of Human Rights in Burmych and Others v Ukraine in Perspective' (2018) 17 The Law and Practice of International Courts and Tribunals, 289 (290).

69 ECtHR, Judgment (GC), 12 October 2017, Burmych and Others $v$ Ukraine, Application Nos. 46852/13 and 4 more, Joint Dissenting Opinion of Judges Yudkivska, Sajó, Bianku, Karakas, De Gaetano, Laffranque and Motoc, para. 28.

70 ECtHR, Judgment, 25 April, 1978, Tyrer $v$ the United Kingdom, Application No. $5856 / 72$. 
steady interpretation. However, the Convention remains just as practically relevant if the Court reminds the member states ever so often about the systemic issues that lead to widespread violations of the Convention. Repetitive cases are nothing but a symptom of long-term non-compliance with existing obligations under the Convention. Holding the member states accountable for failing to comply with the status quo is just as important to keep the Convention 'alive' as the further development of the Convention. Otherwise, the gains in efficiency are made at the expense of compliance.

\section{Efficiency at the Expense of the Court's Legitimacy?}

Even if the Court comes to the conclusion that efficiency must prevail - favouring procedural economy over individual justice - the Court must closely observe how a particular procedural approach impacts its perceived procedural fairness and sociological legitimacy so as to avoid the impression that applicants in repetitive cases are less important than applicants in non-repetitive cases. It is too early to tell if the Court was really 'shooting itself in the foot'71 with the mass strikeout in Burmych or, quite the contrary, protecting itself from falling apart. The answer to this question depends on the invisible glue that underpins international courts: legitimacy. Legitimacy, so the theory, promotes compliance, reinforces authority, and boosts the effectiveness of international courts and tribunals. ${ }^{72}$ Generations of legal scholars, ${ }^{73}$ political scientists, ${ }^{74}$ sociologists, ${ }^{75}$ psychologists $^{76}$ and philosophers ${ }^{77}$ have studied legitimacy, each through their own lens. In fact, there seem to be as many definitions, understandings,

71 ECtHR, Judgment (GC), 12 October 2017, Burmych and Others $v$ Ukraine, Application Nos. 46852/13 and 4 more, Joint Dissenting Opinion, para. 39.

72 See, e.g., Grossman et al. (eds), Legitimacy and International Courts (2018); Wolfrum and Röben (eds), Legitimacy in International Law (2008).

73 See, e.g., Wolfrum and Röben (eds), Legitimacy in International Law (2008).

74 See, e.g., Gibson and Caldeira, 'The Legitimacy of Transnational Legal Institutions: Compliance, Support, and the European Court of Justice' (1995) 39 American Journal of Political Science, 459.

75 See, e.g., Luhmann, Legitimation durch Verfahren (2013); Weber, Wirtschaft und Gesellschaft (2002).

76 See, e.g. Jost and Major (eds), The Psychology of Legitimacy, Emerging Perspectives on Ideology, Justice, and Intergroup Relations (2001).

77 See, e.g., Buchanan, Justice, Legitimacy, and Self-determination, Moral Foundations for International Law (2004). 
and conceptions of legitimacy as there have been scholars writing about it. It is very much an open question whether the widely drawn distinction between normative and sociological legitimacy plays in practice indeed the crucial role that it is given in theory. ${ }^{78}$ For the time being, there is no empirical evidence to support the theoretical arguments advanced by legitimacy scholars. It would be interesting to collect data on the Court's sociological legitimacy and conduct a survey amongst the applicants of the Burmych case to gain new insights into their expectations before filing the application and experiences in dealing with the ECtHR. On that occasion, we should also ask the five named applicants along with the ones listed in the two Appendices to the Burmych judgment about strikeouts: whether they feel treated unfairly and if a public hearing had made a difference. While we can only speculate how many strikeouts they think are too many, it should not strike us as odd if their answer was 12,148.

\section{ANNEX}

Approximate number of applications in which a strikeout decision was rendered

\begin{tabular}{|l|l|l|l|}
\hline Year & $\begin{array}{l}\text { Total number of ap- } \\
\text { plications resolved } \\
\text { by decision }\end{array}$ & $\begin{array}{l}\text { Total number of ap- } \\
\text { plications resolved by } \\
\text { judgment }\end{array}$ & $\begin{array}{l}\text { Approximate number of } \\
\text { applications resolved by } \\
\text { strikeout decision }\end{array}$ \\
\hline $2008^{80}$ & 30,164 & 1,881 & 3,016 \\
\hline $2009^{81}$ & 33,067 & 2,393 & 3,307 \\
\hline $2010^{82}$ & 38,576 & 2,607 & 3,858 \\
\hline $2011^{83}$ & 50,677 & 1,511 & 5,068 \\
\hline $2012^{84}$ & 86,201 & 1,678 & 8,620 \\
\hline
\end{tabular}

78 Tyler, Why People Obey the Law (2006), 57.

79 The calculation is based on an average inadmissibility rate of $90 \%$.

80 ECtHR: Annual Report 2008, 2009, https://www.echr.coe.int/Documents/Annual _report_2008_ENG.pdf, 127.

81 ECtHR, Annual Report 2009, 2010, https:/www.echr.coe.int/Documents/Annual _report_2009_ENG.pdf, 139.

82 ECtHR, Annual Report 2010, 2011, https:/www.echr.coe.int/Documents/Annual _report_2010_ENG.pdf, 145.

83 ECtHR, Annual Report 2011, 2012, https:/www.echr.coe.int/Documents/Annual report_2011_ENG.pdf, 151.

84 ECtHR, Annual Report 2012, 2013, https:/www.echr.coe.int/Documents/Annual _report_2012_ENG.pdf, 149. 


\begin{tabular}{|l|l|l|l|}
\hline Year & $\begin{array}{l}\text { Total number of ap- } \\
\text { plications resolved } \\
\text { by decision }\end{array}$ & $\begin{array}{l}\text { Total number of ap- } \\
\text { plications resolved by } \\
\text { judgment }\end{array}$ & $\begin{array}{l}\text { Approximate number of } \\
\text { applications resolved by } \\
\text { strikeout decision }\end{array}$ \\
\hline $2013^{85}$ & 89,737 & 3,659 & 8,974 \\
\hline $2014^{86}$ & 83,675 & 2,388 & 8,367 \\
\hline $2015^{87}$ & 43,135 & 2,441 & 4,313 \\
\hline $2016^{88}$ & 36,579 & 1,926 & 3,658 \\
\hline $2017^{89}$ & 70,356 & 15,595 & 7,036 \\
\hline $2018^{90}$ & 40,023 & 2,738 & 4,003 \\
\hline Mean & - & $2,424^{91}$ & 5,474 \\
\hline
\end{tabular}

\section{Bibliography}

Berkhuysen, Tom/Van Emmerik, Michael: Legitimacy of European Court of Human Rights Judgments: Procedural Aspects, in: Huls, Nick/Adams, Maurice/Bonhoff Jacco (eds), The Legitimacy of Highest Courts' Rulings (2009), $435 \mathrm{ff}$.

Buchanan, Allen: Justice, Legitimacy, and Self-determination, Moral Foundations for International Law (2004).

Cohen, Harlan Grant/Follesdal, Andreas/Grossman, Nienke/Ulfstein, Geir: Legitimacy and International Courts - A Framework, in: Grossman, Nienke/Cohen, Harlan Grant/Follesdal, Andreas/Ulfstein Geir (eds), Legitimacy and International Courts (2018), 4ff.

Garlicki, Lech: Judicial Deliberations: The Strasbourg Perspective, in: Huls, Nick/ Adams, Maurice/Bonhoff Jacco (eds), The Legitimacy of Highest Courts' Rulings (2009), 389ff.

85 ECtHR, Annual Report 2013, 2014, https://www.echr.coe.int/Documents/Annual report_2013_ENG.pdf, 191.

86 ECtHR, Annual Report 2014, 2015, https:/www.echr.coe.int/Documents/Annual report_2014_ENG.pdf, 165.

87 ECtHR, Annual Report 2015, 2016, https://www.echr.coe.int/Documents/Annual _report_2015_ENG.pdf, 187.

88 ECtHR, Annual Report 2016, 2017, https://www.echr.coe.int/Documents/Annual report_2016_ENG.pdf, 191.

89 ECtHR, Annual Report 2017, 2018, https:/www.echr.coe.int/Documents/Annual report_2017_ENG.pdf, 163.

90 ECtHR, Annual Report 2018, 2019 https://www.echr.coe.int/Documents/Annual report_2018_ENG.pdf, 167.

91 The mean does not take into account the applications included in Burmych and others $v$ Ukraine given that the strikeout was delivered by judgment. 


\section{Edith Wagner}

Gibson, James L./Caldeira, Gregory A.: The Legitimacy of Transnational Legal Institutions: Compliance, Support, and the European Court of Justice, American Journal of Political Science 1995, 459 ff.

Jost, John T./Major Brenda (eds): The Psychology of Legitimacy, Emerging Perspectives on Ideology, Justice, and Intergroup Relations (2001).

Keller, Helen/Forowicz, Magdalena/Engi, Lorenz: Friendly Settlements before the European Court of Human Rights (2010).

Kepner, Tyler: More Strikeouts Than Hits? Welcome to Baseball's Latest Crisis, New York Times, 16 August 2018, https:/www.nytimes.com/2018/08/16/sports/ baseball-mlb-strikeouts.html.

Kindt, Eline: Giving up on individual justice? The effect of state non-execution of a pilot judgment on victims, Netherlands Quarterly of Human Rights 2018, $173 \mathrm{ff}$.

Lasser, Mitchel: Judicial Deliberations, A Comparative Analysis of Judicial Transparency and Legitimacy (2004).

Luhmann, Niklas: Legitimation durch Verfahren, 9th edn. (2013).

Major League Baseball: Official Playing Rules Committee, Official Baseball Rules, 2018 Edition, 126, http://mlb.mlb.com/documents/0/8/0/268272080/2018_Offici al_Baseball_Rules.pdf.

Myjer, Egbert/Sharpe, Jonathan L./Spielmann, Dean (eds): The Conscience of Europe, 50 Years of the European Court of Human Rights (2010).

Nußberger, Angelika: The European Court of Human Rights (2020).

Sainati, Tatiana: Human Rights Class Actions: Rethinking the Pilot-Judgment Procedure at the European Court of Human Rights, Harvard International Law Journal 2015, $147 \mathrm{ff}$.

Scharpf, Fritz: Legitimacy in the multilevel European polity, European Political Science Review 2009, $173 \mathrm{ff}$.

Sellers, Mortimer (ed): Law, Reason, and Emotion (2017).

Tyler, Tom R.: Why People Obey the Law (2006).

Ulfstein, Geir: The Human Rights Treaty Bodies and Legitimacy Challenges, in: Grossman, Nienke/Cohen, Harlan Grant/Follesdal, Andreas/Ulfstein Geir (eds), Legitimacy and International Courts (2018), $284 \mathrm{ff.}$

Ulfstein Geir/Zimmermann, Andreas: Certiorari through the Back Door? The Judgment by the European Court of Human Rights in Burmych and Others v. Ukraine in Perspective, The Law and Practice of International Courts and Tribunals 2018, $289 \mathrm{ff}$.

Verducci, Tom: There Are Too Many Strikeouts in Baseball: Here's How to Fix the Problem, Sports Illustrated, 14 June 2018, https:/www.si.com/mlb/2018/06/14/s trikeouts-effect-major-league-baseball.

Voeten, Eric: The Impartiality of International Judges: Evidence from the European Court of Human Rights, The American Political Science Review 2008, $417 \mathrm{ff}$.

Weber, Max: Wirtschaft und Gesellschaft, 5th rev. edn. (2002).

Wolfrum, Rüdiger/Röben, Volker (eds), Legitimacy in International Law (2008). 